\title{
Program Bantu Diri Terapi Kognitif Perilaku: Harapan bagi Penderita Depresi
}

\author{
Tjipto Susana ${ }^{1}$ \\ Fakultas Psikologi, Universitas Sanata Dharma, Yogyakarta \\ Eko Hari Parmadi, Puspaningtyas Sanjoyo Adi \\ Program Studi Teknik Informatika, Fakultas Sains dan Teknologi \\ Universitas Sanata Dharma, Yogyakarta
}

\begin{abstract}
This article is the first-phased report of a research through a testing of cognitive behavioral therapy module. The subjects involved in this research were 27 students who were experiencing mild to moderate depression. The research design was experiment with a pretest and posttest group. Instruments used in this study were Back Depression Inventory-II (BDI-II), Automatic Thought Questionnaire (ATQ), Dysfunctional Attitude Scale (DAS). The data was analized using paired t-test. Based on qualitative analysis, the results showed that in general it was easy for the students to understand and do the module independently. This module was very helpful for them in managing thoughts and feelings and specifically in the automatic negative thoughts, dysfunctional thinking, and rules. Nevertheless, this module did not cover the core belief. The results of the $t$ test $(t(25)=9.2$; $p<0.001)$ indicated that the Self-Help Cognitive Behavioral Therapy module could reduce the level of depression, automatic negative thoughts and dysfunctional thoughts.
\end{abstract}

Keywords: Cognitive Behavior Therapy, depression, self-help, web-based program

Abstrak. Laporan penelitian ini adalah laporan tahap pertama yang berupa uji coba modul Terapi Kognitif Perilaku. Subjek yang dilibatkan dalam penelitian ini berjumlah 27 mahasiswa yang mengalami depresi ringan sampai sedang. Rancangan penelitiannya adalah eksperimen dengan satu kelompok pra dan purna uji. Alat ukur yang digunakan adalah Back Depression Inventory-II, Automatic Thought Questionnaire, Dysfunctyional Attitude Test. Analisis data yang digunakan adalah paired t-test. Secara kualitatif hasil penelitian menunjukkan bahwa secara umum modul yang dibuat mudah dipahami dan bisa dilakukan secara mandiri oleh subjek. Secara umum modul ini sangat membantu subjek dalam mengelola pikiran dan perasaan. Secara spesifik, modul ini sangat membantu dalam hal pengelolaan pikiran negatif otomatis, cara berpikir yang salah, dan rules, tetapi belum sampai pada core belief. Hasil uji $t\left(t_{(25)}=9,2 ; p<0,001\right)$ menunjukkan bahwa Modul Bantu Diri Terapi Kognitif Perilaku bisa menurunkan tingkat depresi, pikiran negatif otomatis, dan pikiran disfungsional.

Kata kunci: Terapi Kognitif Perilaku, depresi, bantu diri, program berbasis web

${ }^{1}$ Korespondensi mengenai artikel ini dapat melalui: datus3@yahoo.com 
Organisasi Kesehatan Dunia (World Health Organisation $=\mathrm{WHO}$ ) meramalkan bahwa di tahun 2020, secara global gangguan depresi akan menduduki peringkat kedua penyebab kematian prematur dan ketidakmampuan individu (Mukhtar, Oei, \& Yaacob, 2011; National Institute of Mental Health, 2002; World Health Organisation, 2005). Depresi merupakan gangguan kesehatan utama yang berkaitan dengan kerugian ekonomi dan ketidakmampuan (Andrew \& Titov, 2007; Wang, Simon, \& Kessler, 2003). Direktur Bina Pelayanan Kesehatan Jiwa di Indonesia, dokter Pandu Setiawan menyatakan bahwa beban yang ditimbulkan akibat depresi akan jauh lebih besar dari pada penyakit lainnya ("Waspadai Peningkatan", 2012). Depresi ringan dapat menyebabkan menurunnya produktivitas penderita, dan depresi berat dapat menyebabkan penderitanya tidak mampu bekerja.

WHO memprediksi angka gangguan jiwa penduduk dunia meningkat hingga 15\% pada tahun 2015. Peningkatan gangguan kesehatan mental penduduk dunia berjalan seiring dengan laju modernisasi ("Tinas Psikologi", 2012). Chiu (2004) menyatakan bahwa di wilayah Pasifik penderita depresi mayor mencapai tingkat $1,3-5,5 \%$ pada populasi umum. Studi epidemiologi menunjukkan bahwa tingginya jumlah penderita depresi mayor ini hampir setara dengan di negara-negara Barat (Mukhtar, dkk., 2005). Sementara itu di Indonesia, berdasarkan laporan Riset Kesehatan Dasar (Riskesdas) 2007 (“Jumlah Penduduk", 2012; "Tinas Psikologi", 2012) prevalensi gangguan mental emosional (kecemasan dan depresi) orang Indonesia berumur 15 tahun ke atas mencapai $11,6 \%$ dan $0,46 \%$ lainnya mengalami gangguan jiwa berat. Berdasarkan data statistik tahun 2004 tercatat ada sebanyak 1030 orang mencoba bunuh diri dan 705 diantaranya sampai kehilangan nyawa.

Menurut American Psychiatric Association (2010) untuk gangguan depresi ringan sampai sedang, beberapa psikoterapi yang mempunyai bukti empiris bisa mengurangi tingkat keparahan depresi adalah terapi kognitif perilaku, psikoterapi interpersonal, terapi psikodinamik, terapi pemecahan masalah, baik yang dilakukan secara individual maupun kelompok. McGinn (2000) menyatakan bahwa terapi kognitif merupakan tritmen untuk depresi yang diterima secara luas sebagai tritmen utama untuk depresi dan merupakan salah satu dari dua tritmen yang dimasukkan dalam petunjuk tritmen depresi yang dipublikasikan oleh Agency for Health Care and Policy Research (AHCPR). Studi-studi yang dirangkum oleh Epp dan Dobson (2010) menunjukkan bahwa terapi kognitif perilaku efektif untuk gangguan depresi.

Aaron T. Beck dan sejawatnya adalah ahli yang pertama kali mengembangkan terapi kognitif untuk depresi (dalam McGinn, 2000). Lebih dari 40 tahun, model kognitif Beck untuk depresi dan terapi kognitif perilaku (TKP) telah mendapatkan perhatian sebagai subjek penelitian dibandingkan psikoterapi lain untuk depresi (American Psychiatric Association, 2000; Hollon \& DeRubeis dalam Mukhtar, dkk., 2005). Beberapa penelitian termasuk studi meta-analisis yang dirangkum oleh Mukhtar, dkk. (2005) dan Petrocelli (2002) menunjukkan bahwa TKP efektif untuk depresi. Petrocelli (2002) dalam studi meta-analisisnya juga menunjukkan bahwa TKP tidak hanya efektif sebagai terapi individual, tetapi juga sebagai terapi kelompok.

Teori Kognitif secara umum maupun yang dirumuskan oleh Beck menghipotesiskan bahwa cara berpikir negatif tertentu meningkatkan kecenderungan seseorang mengembangkan dan memelihara depresi 
ketika ia mengalami peristiwa hidup yang menekan (McGinn, 2000). Oleh karena itu mengubah cara berpikir menjadi lebih adaptif merupakan salah satu alternatif untuk menurunkan kecenderungan depresi.

Meskipun pada awalnya Beck mengembangkan teori bahwa proses berpikir dan isi pikiran berkaitan dengan depresi, tetapi Beck, dkk. (dalam Dowd, 2004) tidak juga mengklaim bahwa pikiran-pikiran disfungsionalah penyebab utama depresi. Ada peran faktor biologis, sosial, dan psikologis sebagai penyebab depresi. Beck menyatakan bahwa lingkaran hubungan antara pikiran, perasaan atau emosi, dan perilaku menghasilkan lingkaran sindrom depresi. Lingkaran hubungan antara pikiran-perasaan/emosiperilaku inilah yang memperkuat gejalagejala depresi yang diderita oleh seseorang. Menurut teori ini, pikiran disfungsional bisa memunculkan perasaan/emosi tertentu, yang akhirnya diikuti oleh perilaku atau tindakan yang selaras dengan pikiran dan perasaan yang muncul. Demikian halnya, perasaan atau emosi negatif bisa memunculkan pikiran disfungsional yang akhirnya menghasilkan perilaku tertentu. Perilaku yang tidak adaptif juga bisa menghasilkan perasaan atau emosi negatif dan akhirnya memunculkan pikiran disfungsional. Oleh karena itu dalam menangani klien depresi, Beck dan kawan-kawan mengembangkan pendekatan kognitif-perilaku.

Dalam terapi kognitif perilaku, gejala depresi atau kecemasan bisa dikurangi dengan langkah pertama memulai dari merestrukturisasi pikiran yang disfungsional. Asumsinya perubahan pikiran akan menyebabkan terjadinya perubahan perasaan/emosi dan perilaku. Tetapi tidak jarang pula gejala depresi akan berkurang ketika intervensi dimulai dari pengolahan perasaan dan perilaku. Intensitas perasaan negatif yang berkurang akan berdampak pada berkurangnya kecenderungan munculnya pikiran yang disfungsional. Oleh karena itu urutan dalam upaya pengurangan gejala depresi bisa dimulai dari pikiran, tetapi bisa juga dimulai dari perasaan atau perilaku (Beck dalam Dowd, 2004).

Jadi terapi kognitif perilaku berfokus pada pemrosesan informasi dan perilaku yang bersifat depresif. Aspek yang diintervensi adalah kognisi, pikiran/emosi (termasuk reaksi fisiologis), dan perilaku. Pada ranah kognisi, subjek belajar menerapkan teknik merestrukturisasi kognisi sehingga cara berpikirnya menjadi lebih logis dan adaptif. Pada saat melakukan identifikasi dan restrukturisasi pikiran disfungsional, individu harus mampu memeriksa pikiran otomatis yang muncul sebagai sebuah gejala psikologis, bukan sebagai fakta atau realitas. Kemampuan ini oleh Beck disebut sebagai decentering.

Kemampuan decentering ini diajarkan dalam bentuk mencari fakta objektif dari pikiran dan perasaan. Dari pencarian fakta ini diharapkan muncul kesadaran atau pencerahan bahwa apa yang selama ini diyakini sebagai kebenaran, ternyata hanyalah berupa asumsi, keyakinan, pikiran, atau perasaan yang bersifat subjektif.

Dalam perkembangan selanjutnya, ketika teori mindfulness yang berakar dari ajaran Budhisme, mulai dikenal kembali di Barat dan dikembangkan oleh Kabat-Zinn pada tahun 1980-an (dalam Fruzetti \& Erikson, 2010), maka salah satu cara melakukan decentering bisa melalui kegiatankegiatan atau latihan-latihan memusatkan perhatian dengan cara-cara tertentu yang bertujuan untuk menyadari saat ini dan bersifat bebas penilaiaan (Kabat-Zinn dalam Idusohan-Moizer, Sawicka, Dendles, \& Albany (2013). 
Latihan meditasi pernapasan dan yoga dapat membantu seseorang lebih menyadari kekinian, termasuk perubahan pikiran dan kondisi tubuh dari waktu ke waktu. Sejalan dengan teori Beck bahwa ada hubungan antara pikiran, perasaan/ emosi (termasuk gejala fisiologis), dan perilaku, maka latihan mindfulness ini akan meningkatkan kesadaran individu bahwa ada hubungan antara pola pikir/cara berpikir, perasaan/emosi, dan perilaku.

Mindfulness dapat membantu individu mengenali dan mengamati pola pikiran dengan lebih jelas dan membuat jarak dengan pikiran yang biasanya pikiranpikiran tersebut memengaruhi suasana hati mereka menjadi lebih buruk. Mindfulness juga mengurangi kecenderungan untuk menghentikan atau menghindari pikiran otomatis yang tidak konstruktif. Mindfulness meningkatkan kemampuan individu untuk menyadari dan menormalkan emosi dan sensasi tubuh tanpa harus berusaha keras untuk menentang atau menghentikannya.

Selain membantu meningkatkan kemampuan metakognisi dan kesadaran, mindfulness dalam bentuk latihan meditasi secara biologis juga langsung berdampak pada reduksi distres. Penelitian-penelitian yang dilakukan menunjukkan bahwa praktik meditasi menimbulkan perubahan aktivitas gelombang otak (korteks prefrontal, sistem limbik, dan hipotalamus) yang bersifat menungkatkan regulasi emosi (Davidson, dkk., 2003); meningkatkan aktivitas parasimpatik dan detak jantung yang bersifat meningkatkan kondisi relaksasi (Dusek, Otu, Wohlhueter, Bhasin, Zerbini, Joseph, dkk., 2008; Hölzel, Carmody, Congleton, Yerramsetti, Gard, \& Lazar, 2011); meningkatkan neurotransmiter yang memengaruhi kondisi emosi positif seperti melatonin, serotonin, betaendorphin, dan acetylcholine; menurunkan neurotransmiter yang bersifat meningkatkan distres seperti nor-epinephrine dan kortisol (Infante, dkk., 1998; MacLean, dkk., 1997; Newberg \& Iversen, 2003; Tolley, Armstrong, Norman, \& Sali A 2003); dan meningkatkan kekebalan tubuh (Davidson, dkk., 2003).

Bukti-bukti empiris tentang dampak meditasi atau latihan mindfulness tersebut mendukung teori pengobatan tubuh dan pikiran yang dipopulerkan oleh Norm Shealy di tahun 1978, Jon Kabat-Zinn di tahun 1979, Joan Borysenko dan Bernie Siegel di tahun 1980-an (dalam Buczinky, $\mathrm{tt})$. Teori ini menyatakan bahwa ada kesatuan dan interaksi saling memengaruhi antara tubuh, pikiran, dan spirit. Oleh karena itu pengobatan pada gangguan fisik maupun mental tidak bisa dilepaskan dari pengolahan ketiga aspek tersebut.

Berdasarkan teori-teori dan hasil penelitian yang sudah diuraikan sebelumnya, maka dalam penelitian ini, teori utama yang digunakan untuk menyusun modul TKP adalah teori Beck dan pengobatan pikiran-tubuh (mind-body medicine). Kedua teori ini menjelaskan hubungan antara pikiran, perasaan/emosi, perilaku, dan tubuh.

Zeiss, Lewinsohn, dan Munoz (dalam Munoz, dkk., 2000) menyatakan ada empat elemen kunci yang paling penting dalam TKP yaitu: (1) memantapkan penalaran dalam intervensi, (2) melatih keterampilan praktis untuk mengubah suasana hati yang berkaitan dengan pikiran dan perilaku, (3) meningkatkan praktik keterampilan di luar sesi terapi, dan (4) atribusi perbaikan diri pada keterampilan diri bukan perjumpaan dengan terapis. Berdasarkan empat elemen kunci tersebut, terutama elemen yang ketiga dan keempat, maka TKP yang mulanya muncul sebagai terapi yang bersifat tatap muka, mulai dikembangkan menjadi 
terapi yang bersifat bantu diri, bahkan dengan berkembangnya teknologi digital, TKP mulai berkembang menjadi program bantu diri berbasis web (Clarke, dkk., 2009). Studi meta-analisis yang dilakukan oleh Andersson dan Cuijpers (2009) menunjukkan bahwa tritmen berbasis web ini secara empiris cukup menjanjikan.

Menurut Berger, dkk. (2011) metode TKP berbasis web ini mampu mengatasi beberapa hambatan untuk mendapatkan pelayanan langsung dari psikolog, yaitu terbatasnya jumlah klinisi, stigma, kesulitan berkonsultasi karena kesibukan, dan beaya. Mengingat Indonesia juga tidak terlepas dari hambatan-hambatan seperti yang diungkapkan Berger dkk., misalnya keberadaan psikolog klinis ataupun psikiater masih dibawah rasio ideal yaitu 0,22:100 ribu, padahal standar yang diberikan oleh WHO sebesar 1:30 ribu. (Retnowati, 2011; "Tinas Psikologi", 2012), maka pengembangan TKP yang bersifat bantu diri baik yang berbasis web maupun tidak, sangat dibutuhkan.

Di Indonesia, program bantu diri untuk depresi baik yang berupa buku maupun yang berbasis internet masih belum banyak dikembangkan. Program bantu diri berbasis internet yang dikembangkan di Indonesia masih berupa web atau blog yang berisi biblioterapi, tips, skala sederhana, dan beberapa kuis singkat. Padahal hasil penelitian Clarke, dkk. (2009) menunjukkan bahwa program yang berisi tutorial interaktif yang memberikan umpan balik secara personal mirip dengan terapi tatap muka merupakan elemen yang paling efektif.

Pengembangan program bantu diri berbasis web ini akan sangat berguna bagi penderita gangguan depresi ringan dan sedang. Menurut Burns (1988), penderita depresi ringan sampai sedang masih bisa dan akan mendapat manfaat dari program bantu diri. Sementara itu bagi penderita depresi berat dan juga disfungsional pikir berat, Burns menganjurkan untuk melakukan terapi tatap muka dengan psikoterapis.

Setelah melihat persoalan penanganan depresi di Indonesia yang masih belum bisa menjangkau sebagian besar penderita, besarnya manfaat terapi kognitif perilaku berbasis internet/web, dan belum banyak dikembangkannya program yang interaktif, maka terbuka peluang untuk mengembangkan modul TKP bantu diri yang bersifat interaktif. Penelitian ini bertujuan merancang dan mengujicobakan modul TKP bantu diri yang nantinya akan dikembangkan menjadi terapi kognitif perilaku yang bersifat interaktif dan berbasis web yang akan sangat membantu upaya pencegahan dan tindakan kuratif bagi penderita depresi ringan maupun sedang di Indonesia.

\section{Metode}

\section{Penyusunan modul TKP bantu diri}

Tahap pertama, dilakukan penyusunan modul oleh peneliti. Beberapa referensi yang menjadi dasar untuk penyusunan modul adalah: (1) Burns, (1988) yang berjudul Terapi kognitif: Pendekatan baru bagi penanganan depresi (Santoso, terj.). Jakarta: Penerbit Erlangga. (karya asli terbit 1980). (2) Neenan, M., \& Dryden, W. (2004). Cognitive Therapy: 100 key points $\mathcal{E}$ techniques. New York: Brunner-Routledge, dan (3) www.get.gg/selfhelpassist.htm. An Introductory self help course in Cognitive Behavior Therapy. Carol Vivyan 2009-2013.

Buku karya Burns (1988) serta Neenan dan Dryden (2004) dipilih karena kedua buku ini mendasarkan tulisannya pada teori Beck sebagai pencetus teori dan terapi kognitif perilaku. Sementara TKP 
bantu diri Vivyan di pilih karena ia mengembangkan TKP bantu diri berbasis web dan berisi: (1) pelatihan keterampilan praktis untuk mengubah suasana hati yang berkaitan dengan pikiran dan perilaku, dan (2) memberikan latihan-latihan yang berdasarkan integrasi pikiran-tubuh (mind-body integration skill).

Pada proses penyusunan modul, peneliti berdiskusi dan berkonsultasi dengan beberapa ahli yaitu psikolog klinis yang juga seorang akademisi. Ahli yang dilibatkan dalam penilaian modul ini sudah melakukan praktik klinis lebih dari 20 tahun dan juga bersertifikat sebagai Terapis Kognitif Perilaku.

\section{Subjek}

Subjek penelitian yang dilibatkan dalam penelitian ini berjumlah 27 (8 lakilaki dan 19 perempuan). Tidak seimbangnya jumlah laki-laki dan perempuan ini merupakan cerminan dari kenyataan bahwa kecenderungan perempuan untuk menderita depresi lebih tinggi dibandingkan laki-laki. Studi internasional (American Psychiatric Association, 2003; Goldman, 1999; Immerman \& Mackey, 2003; Kane \& Garber, 2004; Mackey \& Immerman, 2000; NIMH, 2006) menunjukkan bahwa prevalensi perempuan untuk menderita depresi dan somatisasi lebih tinggi dibandingkan laki-laki. WHO (2001) melaporkan bahwa pada tahun 2000, prevalensi depresi unipolar pada perempuan sebesar 3,2\% dan laki-laki 1,9\%; sedangkan untuk episode depresi, prevalensi perempuan sebesar 9,5\% dan laki- laki sebesar 5,8\%.

Mereka adalah mahasiswa dengan rata-rata usia 20,44 tahun $(S D=3,82)$. Pemilihan subjek yang berstatus mahasiswa dan berusia 18 tahun ke atas ini didasarkan pada pertimbangan sebagai berikut: (1) di Indonesia, berdasarkan laporan Riset Kesehatan Dasar 2007 ("Jumlah Pendu- duk", 2012; “Tinas Psikologi”, 2012; ) prevalensi gangguan mental emosional (kecemasan dan depresi) orang Indonesia berumur 15 tahun ke atas mencapai 11,6\% dan $0,46 \%$ lainnya mengalami gangguan jiwa berat; (2) Menurut teori Piaget perkembangan kognitif seseorang yang berusia 18 tahun ke atas sudah mencapai tahap operasional formal atau mampu berpikir abstrak; (3) mahasiswa di Indonesia pada umumnya adalah pengguna internet secara aktif, maka lebih sesuai sebagai media uji coba pengembangan modul yang nantinya akan dibuat berbasis internet/web.

Subjek yang diikutsertakan dalam penelitian ini adalah mahasiswa yang mengalami depresi ringan sampai sedang (skor depresi dengan skala BDI-II berkisar antara 17 - 30, dan tidak mempunyai gejala bunuh diri). Rata-rata skor depresi subjek adalah 23,37 $(S D=5,1)$. Penetapan batas skor depresi dengan BDI-II sebesar 17 - 30 dan tidak mempunyai gejala bunuh diri, didasarkan pada peneltian Ginting, dkk. (2013) bahwa skor batas untuk depresi sedang di Indonesia adalah 17, dan juga kriteria yang dibuat oleh Burns (1988). Semua subjek bukanlah pasien depresi yang sudah mendapatkan diagnosis dari psikolog atau psikiater dan tidak sedang menjadi pasien untuk mendapatkan terapi atau intervensi psikologis maupun medis. Mereka juga tidak mengalami gejala-gejala psikotik, seperti waham, halusinasi, kerusakan berpikir logis. Kriteria ini didasarkan pada ketentuan yang dibuat oleh para ahli (American Psychiatric Association, 2003; Burns, 1988; Munoz, dkk., 2000) bahwa TKP, terutama yang bersifat bantu diri lebih sesuai untuk orang yang mengalami depresi ringan sampai sedang dan tidak mengalami gangguan mental lain seperti psikotik, gangguan kepribadian, kecanduan alkohol atau obat-obatan terlarang. Untuk penderita depresi berat dan disertai 
gangguan-gangguan lain, tetap dianjurkan untuk mengikuti terapi tatap muka secara intensif dengan ahli.

Penjaringan subjek dilakukan dengan cara sebagai berikut: (1) Memberikan skala BDI-II pada mahasiswa S1. (2) Mewawancara subjek untuk memperoleh data kecanduan, gangguan psikologis, gangguan fisik, dan status pengobatan. (3) Menyeleksi subjek yang memiliki skor depresi 17 - 30 yang diukur dengan BDI-II dan tidak mempunyai gejala bunuh diri, tidak mengalami kecanduan, tidak mengalami gangguan psikologis lain, tidak mengalami gangguan fisik yang bisa memengaruhi proses terapi, dan tidak sedang menjalani pengobatan medis maupun tritmen psikologis, dan (4) Memberikan penawaran ke subjek untuk terlibat dalam penelitian dan memberikan informed consent pada subjek yang bersedia terlibat dalam penelitian.

\section{Pengambilan sampel}

Metode yang digunakan untuk pengambilan sampel adalah nonprobabilitas dengan teknik purposif (Kerlinger, 1990; Leedy \& Ormrod,2005). Subjek dalam penelitian ini dipilih berdasarkan kriteria tertentu, yaitu: (1) Berusia 18 tahun ke atas. (2) Mahasiswa S1. (3) Memiliki skor depresi 17 - 30 yang diukur dengan BDI-II dan tidak mempunyai gejala bunuh diri. (4) Tidak mengalami kecanduan alkohol atau obat-obatan terlarang. (5) Tidak mengalami gangguan psikologis lain. (6) Tidak mengalami gangguan fisik yang bisa memengaruhi proses terapi, dan (7) Tidak sedang menjalani pengobatan medis maupun tritmen psikologis yang bisa memengaruhi terapi.

\section{Alat ukur atau skala}

Ada tiga skala yang digunakan dalam penelitian ini, yaitu Beck Dpression
Inventory-II (BDI-II), Automatic Thougth Questionnaire (ATQ), dan Dysfunctional Attitude Scale (DAS). ATQ dan DAS diadaptasi sesuai dengan prosedur yang ditetapkan oleh International Test Commission Guidelines for Test Adaptation (International Test Commission, 2010). Pertama kedua skala ini diterjemahkan ke dalam Bahasa Indonesia oleh dua orang penerjemah profesional. Kemudian diterjemahkan balik ke dalam Bahasa Inggris oleh dua orang Indonesia yang pernah tinggal di Negara yang berbahasa Inggris. Kedua penerjemah balik ini mempunyai kemampuan dwi bahasa yaitu Bahasa Indonesia dan Bahasa Inggris dan mempunyai latar belakang pendidikan psikologi. Hasil terjemahan balik ini kemudian dicocokkan dengan versi aslinya. Dalam proses mencocokan dan adaptasi bahasa ini dilakukan diskusi antara peneliti, penerjemah, dua staf pengajar di bidang psikologi, dan beberapa mahasiswa psikologi. Langkah selanjutnya adalah melakukan uji validitas dan reliabilitas skala. BDIII yang digunakan dalam penelitian ini adalah BDI-II versi Bahasa Indonesia yang sudah diadaptasi oleh Ginting, dkk. (2013).

Beck Dpression Inventor-II (BDI-II). BDI-II terdiri dari 21 aitem yang bersifat laporan diri yang digunakan untuk mengukur tingkat keparahan gejala depresi secara subjektif (Beck, Steer, \& Brown, 1996). Setiap respon jawaban dinilai berdasarkan skala 0 (tidak mengalami) sampai 3 (berat). Skala ini berisi aspek kognitif (misalnya pikiran tentang kegagalan di masa lalu), emosi/afeksi (misalnya kesedihan), dan somatik/vegetatif (misalnya kelelahan) (Beck, Steer, Brown, \& van der Does, 2002). BDI-II mempunyai validitas konstruk (concurrent/convergent and discriminant validity) yang baik. Hal ini ditunjukkan oleh penelitian Ginting, dkk. (2013) yaitu adanya, korelasi positif antara 
BDI-II dengan skala lain yang mengukur gejala-gejala sejenis yaitu dengan Type $D$ Personality Scale (DS14, mengukur kecenderungan karakteristik kepribadian yang mengarah pada afek negatif dan inhibisi sosial $) \quad(r=0,52 ; \quad p<0,01)$, Basic Anxiety Inventory (BAI, mengukur kecemasan) $(r=0,52, \quad p<0,01)$ dan berkorelasi negatif dengan skala yang mengukur kondisi yang berlawanan dengan depresi, yaitu dengan Multidimensional Scale of Perceived Social Support (MSPSS, mengukur persepsi terhadap dukungan sosial) $(r=-0,39, p<0,01)$ dan Life Orientation Test-Revised version (LOT-R, mengukur optimisme) $(r=-0,46$, $p<0,01)$. Uji coba yang dilakukan peneliti juga menunjukkan hal yang sama, yaitu BDI-II berkorelasi positif dengan skala CDS (Carroll Depression Scales) $(r=0,72$; $p<0,01)$, skala CES-D (Center for Epidemiologic Studies Depression Scale $) \quad(r=0,74$; $p<0,01)$, ATQ (Automatic Thoughts Questionnaire, mengukur pikiran negatif) $(r=0,71$; $p<0,01$ ), dan DAS (Disfunctional Attitude Scale, mengukur sikap yang disfungsional) $(r=0,35 ; \quad p<0,01)$, dan berkorelasi negatif dengan skala yang mengukur kebahagiaan (SHS=Subjective Happiness Scale) $(r=-0,48$; $p<0,001)$. Penelitian Ginting, dkk. (2013) menunjukkan bahwa BDI-II mampu membedakan antara individu yang depresi dan tidak depresi dan mempunyai konsistensi internal 0,90 serta reliabiltas tes ulang sebesar 0,55 $(p<0,01)$.

Automatic Thoughts Questionnaire (ATQ). ATQ merupakan alat ukur yang berisi 30 aitem yang digunakan untuk mengukur frekuensi pikiran negatif otomatis tentang diri (Hollon \& Kendall, 1980). Pikiran-pikiran negatif ini mempunyai peran penting dalam mengembangkan dan memelihara aneka psikopatologi, termasuk depresi. ATQ mengukur empat aspek pikiran otomatis, yaitu salah suai personal dan keinginan untuk berubah, harapan dan harga diri negatif, harga diri rendah, dan ketidakberdayaan. ATQ mengukur seberapa sering seseorang mempunyai pikiran negatif, dengan lima skala yaitu dari tidak pernah (1) sampai selalu (5). Rentang skor total yang diperoleh berkisar antara $30-150$. Dari beberapa penelitian (misalnya Hollon \& Kendal, 1980 memperoleh $\alpha=0,97$; Harrell \& Ryon, 1983 memperoleh $\alpha=0,98$; Kazdin, 1990 memperoleh $\alpha=0,94)$ ATQ menunjukkan konsistensi internal yang sangat tinggi. Hasil perhitungan peneliti juga menunjukkan bahwa ATQ mempunyai konsistensi internal yang tinggi yang ditunjukkan oleh koefisen Alpha Cronbach sebesar 0,95. ATQ mempunyai validitas diskriminan yang baik, yaitu mampu membedakan antara pasien yang depresi dan nondepresi (Hollon \& Kendal, 1980; Harrell \& Ryon, 1983; Kazdin, 1990). Hasil uji validitas konvergen (concurrent validity) yang dilakukan peneliti dan hasil-hasil penelitian sebelumnya (Harrell \& Ryon, 1983; Kazdin, 1990) menunjukkan bahwa ATQ berkorelasi dengan konstruk yang sama yaitu dengan BDI-II, MMPI-D, DAS, CES-D, CDS, aneka pengukuran disfungsi pikiran. Dari uji coba penelitian ini ATQ juga mempunyai validitas diskriman yang baik, yaitu berkorelasi negatif dengan skala kebahagiaan $(r=-0,52 ; p<0,01)$.

Dysfunctional Attitude Scale (DAS). DAS merupakan alar ukur yang dirancang untuk mengidentifikasi penyimpangan kognisi, yang mungkin sebagian penyimpangan ini berkaitan dengan depresi (Weissman \& Beck, 1978). Skala ini berisi 40 aitem yang dikembangkan atas dasar model terapi kognitif Beck dan berisi empat faktor mendasar, yaitu: perfeksionisme, mencari perhatian orang lain (konfirmasi), mencari kepuasan orang lain, dan evaluasi fungsional (Ebrahimi, dkk., 2012). Setiap jawaban akan diberi skor 
berdasarkan tujuh skala, yaitu; (1) sangat tidak setuju sampai (7) sangat setuju. Skor terendah yang diperoleh adalah 40 dan skor tertinggi 280. Penelitian Ciarrochi dan Bilich (2006) menunjukkan bahwa DAS mempunyai konsistensi internal yang baik, yaitu koefisien alpha-nya berkisar antara 0,84 - 0,92. Hasil uji konsistensi internal pada penelitian ini juga menunjukkan hal yang sama, yang ditunjukkan oleh koefisen alpha sebesar 0,874 . Dari uji tes ulang, DAS juga menunjukkan reliabilitas yang baik, yaitu berkisar antara 0,80 - 0,92 (Ciarrochi \& Bilich, 2006). Validitas konvergen (concurrent validity) yang diperoleh dari penelitian ini menunjukkan bahwa DAS berkorelasi positif dengan beberapa skala yang mengukur konstruk yang serupa, yaitu dengan ATQ $(r=0,48$; $p<0,01), \quad$ BDI-II $\quad(r=0,35 ; \quad p<0,01), \quad$ CDS $(r=0,47 ; p<0,01)$, CES-D $(r=0,41 ; p<0,01)$. DAS juga mempunyai validitas diskriminan yang baik, yaitu mampu membedakan antara individu yang depresi dan nondepresi (Ciarrochi \& Bilich, 2006) dan ditunjukkan dari korelasi negatif DAS dengan skor skala kebahagiaan $(r=-0,50 ; p<0,01)$.

\section{Modul Bantu Diri Terapi Kognitif Perilaku}

Modul ini sebagian besar merupakan hasil pengembangan dari modul bantu diri berbasis web yang disusun oleh Vivyan ditambah dengan beberapa pengukuran pikiran disfungsional dan gejala depresi, beberapa teknik dari buku bantu diri Burns (1988) dan terapi kognitif yang ditulis oleh Neenan dan Dryden (2004). Pemilihan referensi-referensi tersebut didasarkan pada pertimbangan bahwa acuan tersebut sesuai dengan grand theory yang digunakan yaitu teori Beck tentang depresi dan teori body-mind medicine yang sudah dijelaskan di bagian pendahuluan.

Modul terdiri dari lima bagian besar, yaitu pengantar, mengubah pikiran, mengubah perilaku, menjaga jarak dengan pikiran (mind-body medicine) dan mempertahankan kondisi positif. Berikut adalah penjelasan per bagian modul.

Pengantar terdiri dari pemahaman konsep depresi, hubungan antara pikiranperasaan-perilaku-respon fisiologis, dan terapi kognitif perilaku. Pada bagian pengantar ini kegiatan terdiri dari pemahaman diri dan pemahaman kognitif. Oleh karena itu pada bagian awal individu akan diminta melakukan asesmen diri.

Setelah memahami diri, persoalan, dan bagaimana persoalan tersebut muncul, maka pada bagian kedua individu akan diajak untuk memahami pikiran, mengevaluasi, dan mengubah pikiran menjadi lebih konstruktif. Sama seperti pada bagian pengantar, bagian kedua ini juga berisi kegiatan pemahaman diri, latihan, dan pemahaman konsep.

Bagian ketiga berupa perubahan melalui perilaku. Pada bagian ini individu diajak untuk melakukan kegiatan-kegiatan positif yang bisa meningkatkan perasaan bermakna.

Bagian keempat berisi latihan menjaga jarak dengan pikiran, menerima pikiran dan perasaan, serta mengurangi reaktivitas terhadap pikiran dan perasaan. Di sini dilatihkan aneka latihan kesadaran, relaksasi, dan meditasi.

Bagian kelima berisi tentang strategi mempertahankan kondisi positif. Dengan keterampilan ini diharapkan individu bisa mengurangi risiko kembali ke kondisi depresi.

\section{Rancangan uji coba modul}

Modul diujicobakan pada subjek yang mengalami depresi ringan sampai sedang dalam bentuk terapi kelompok. Dalam penyampaian modul, studi mandiri dan pekerjaan rumah diberikan dalam porsi 
yang lebih banyak dibandingkan lekturet (atau ceramah). Model terapi kelompok ini dipilih dengan tujuan dimungkinkannya terjadi sharing pengalaman dan diskusi yang sangat berguna bagi evaluasi modul. Porsi pekerjaan rumah yang berupa latihan dan studi mandiri yang cukup besar dimaksudkan untuk menguji cobakan modul ini sebagai modul bantu diri. Pada setiap sesi pertemuan ada evaluasi dari pengamat dan dari subjek penelitian.

Selain evaluasi secara kualitatif, pada awalnya penelitian ini dirancang juga untuk menguji efek terapi dengan rancangan eksperimen lapangan klasik (Leedy \& Ormrod,2005; Neuman, 2000; Shaughnessy, Zechmeister, \& Zechmeister, 2007) atau yang disebut Kelompok Kontrol Pra dan Purna Uji (Kerlinger, 1990; Leedy \& Ormrod, 2005). Pada rancangan ini subjek dimasukkan kedalam kelompok eksprerimen dan kontrol dengan penunjukkan acak (random assignment).

Meskipun awalnya rancangan penelitian berupa Kelompok Kontrol Pra dan Purna uji, tetapi pada akhir eksperimen, ternyata hanya lima orang dari kelompok kontrol yang mengerjakan purna uji, dengan demikian rancangan penelitian awal tidak bisa diterapkan.

Rancangan penelitian akhir berupa satu kelompok pra dan purna uji (Kerlinger, 1990, Shaughnessy, Zechmeister, \& Zechmeister, 2007). Kelemahan dari rancangan ini sebenarnya adalah kontrol terhadap variabel-variabel pencemar kurang baik, misalnya efek pengukuran (pengukuran pra uji memengaruhi perubahan perilaku subjek), efek sejarah (selama jeda pengukuran pra dan purna uji ada faktor-faktor lain di luar terapi yang ikut berperan terhadap perubahan perilaku), kematangan (misalnya pertambahan usia mental atau peristiwa hidup yang meningkatkan kematangan psikologis yang ikut berperan dalam perubahan perilaku), dan efek regresi (yaitu skor-skor yang bergerak menuju harga tengah sebagai akibat ketidak sempurnaan hubungan antara skor pra uji dan purna uji (Kerlinger, 1990, Shaughnessy, Zechmeister, \& Zechmeister, 2007).

\section{Analisis data}

Karena hanya terdapat satu kelompok dengan pra dan purna uji, maka data dianalisis menggunakan uji $t$ berpasangan (paired $t$-test non-independent $t$-test).

\section{$\mathrm{H}$ a $\mathrm{s}$ i 1}

\section{Penyusunan Modul}

Dari hasil diksusi dengan para reviewer modul muncul beberapa masukan sebagai berikut: (1) Terapi sebaiknya bisa membawa seseorang kepada kesadaran perasaan dan pikiran karena tidak setiap orang dengan mudah mengidentifikasi dan menguji pikiran. Maka latihan-latihan kesadaran perasaan dan pikiran perlu ada, tidak sekedar latihan menganilisis pikiran. Dalam kasus seperti ini, kemampuan mengamati dan tidak bereaksi terhadap pikiran akan membantu seseorang mengurangi reaktivitas, meningkatkan ketenangan, dan penerimaan terhadap menerima pikiran dan perasaannya. (2) Terapi kognitif perilaku yang berupa bantu diri, sebaiknya sederhana dan mudah dipahami. Kegiatan-kegiatan yang dirancang sebaiknya bisa membawa pada pemahaman dan kesadaran kognitif tentang pemikiran yang tidak realistis, dan (3) Jika memang ingin dibuat model web, sebaiknya web tersebut bersifat interaktif.

Berdasarkan masukan-masukan tersebut, maka modul bantu diri TKP diperbaiki. Secara umum modul ini terdiri dari lima bagian besar, yaitu pengantar, meng- 
ubah pikiran, mengubah perilaku, menjaga jarak dengan pikiran (mind-body medicine) dan mempertahankan kondisi positif. Bagian mind-body medicine mengakomodasi masukan reviewer, yaitu memberikan latihan kesadaran, relaksasi, dan meditasi. Sementara itu latihan-latihan yang berupa membuat catatan kejadian, pikiran, dan perasaan dimaksudkan untuk memfasilitasi pemahaman subjek terhadap konsep-konsep TKP secara lebih mudah dan sederhana.

Skala tentang pikiran negatif dan disfungsional dimaksudkan untuk mem- berikan umpan balik dan mempermudah subjek mengidentifikasi pikiran-pikiran negatif maupun yang disfungsional yang berkaitan dengan perasaan depresinya. Dalam modul ini disediakan juga bagan dan gambar-gambar sebagai rangkuman sekaligus pengingat sederhana tentang langkah-langkah mengelola pikiran dan perasaan yang berguna untuk mengurangi pikiran dan perasaan negatif.

Berdasarkan lima bagian utama tersebut, modul dikembangkan menjadi beberapa topik sebagaimana tercantum pada Tabel 1.

Tabel 1

Kisi-Kisi Modul Bantu Diri Terapi Kognitif Perilaku

\begin{tabular}{|c|c|c|c|}
\hline No. & Topik & Kegiatan & Tujuan \\
\hline 1 & $\begin{array}{l}\text { Mengukur suasana } \\
\text { hati }\end{array}$ & $\begin{array}{l}\text { - Mengisi skala Depresi } \\
\text { - Membaca handout konsep yang } \\
\text { mendasari hubungan antara } \\
\text { pikiran, perasaan, dan perilaku }\end{array}$ & $\begin{array}{l}\text { - Asesmen awal terhadap kon- } \\
\text { disi depresi } \\
\text { - Memberikan masukan pada } \\
\text { subjek tentang kondisi suasana } \\
\text { hatinya } \\
\text { - Memberikan pemahaman } \\
\text { tentan hubungan antara } \\
\text { pikiran, perasaan, dan perilaku } \\
\text { - Memberikan dasar-dasar } \\
\text { pemikiran terapi kognitif } \\
\text { perilaku }\end{array}$ \\
\hline 2 & $\begin{array}{l}\text { Lihat pikiran } \\
\text { otomatis Anda }\end{array}$ & $\begin{array}{l}\text { - Mengisi skala pikiran negatif dan } \\
\text { disfungsional } \\
\text { - Membaca handout tentang cara } \\
\text { mengidentifikasi pikiran } \\
\text { - Mengerjakan lembar observasi } \\
\text { pikiran }\end{array}$ & $\begin{array}{l}\text { - Mengidentifikasi pikiran- } \\
\text { pikiran negatif dan } \\
\text { disfungsional }\end{array}$ \\
\hline 3 & \multicolumn{3}{|c|}{ Membuat perubahan pikiran } \\
\hline & a. Menguji pikiran & $\begin{array}{l}\text { - Membaca handout dengan topik } \\
\text { bagaimana mengubah pikiran } \\
\text { dan membedakan fakta dan } \\
\text { pendapat } \\
\text { - Berlatih menguji pikiran }\end{array}$ & $\begin{array}{l}\text { - Membedakan antara fakta dan } \\
\text { pendapat } \\
\text { - Menguji pikiran yang tidak } \\
\text { rasional }\end{array}$ \\
\hline & $\begin{array}{l}\text { b. Mencari pikiran } \\
\text { alternatif }\end{array}$ & $\begin{array}{l}\text { Membaca handout tentang } \\
\text { mencari pikiran alternatif } \\
\text { Belajar menguji pikiran dan } \\
\text { mencari pikiran alternatif yang } \\
\text { lebih rasional }\end{array}$ & $\begin{array}{l}\text { Menguji pikiran yang tidak } \\
\text { rasional dan membuat } \\
\text { tanggapan yang lebih } \\
\text { rasional }\end{array}$ \\
\hline
\end{tabular}




\begin{tabular}{|c|c|c|c|}
\hline No. & Topik & Kegiatan & Tujuan \\
\hline 4 & $\begin{array}{l}\text { Memperbaiki } \\
\text { peraturan harus }\end{array}$ & $\begin{array}{l}\text { Membaca handout tentang rules } \\
\text { yang menjadi sumber gangguan } \\
\text { perasaan dan perilaku } \\
\text { - Berlatih menemukan rules dalam } \\
\text { diri dan membuat pernyataan } \\
\text { baru yang lebih fleksibel }\end{array}$ & $\begin{array}{l}\text { - Menemukan rules atau } \\
\text { peraturan keharusan yang } \\
\text { tidak rasional, yang } \\
\text { menyebabkan perasaan negatif } \\
\text { dan perilaku tidak konstruktif } \\
\text { - Mengubah pikiran yang kaku } \\
\text { dan mengikat menjadi lebih } \\
\text { terbuka dan fleksibel }\end{array}$ \\
\hline 5 & $\begin{array}{l}\text { Membuat Perubaha } \\
\text { a. Melakukan } \\
\text { kegiatan untuk } \\
\text { mengurangi } \\
\text { tekanan emosi }\end{array}$ & $\begin{array}{l}\text { n perilaku } \\
\text { - Membaca handout tentang } \\
\text { "Membuat Perubahan-Perilaku" } \\
\text { - Melakukan refleksi kegiatan } \\
\text { - Melakukan kegiatan-kegiatan } \\
\text { yang bisa mengubah suasana } \\
\text { hati atau perasaan }\end{array}$ & $\begin{array}{l}\text { - Mengubah perasaan melalui } \\
\text { perilaku }\end{array}$ \\
\hline & $\begin{array}{l}\text { b. Membuat } \\
\text { Jadwal Kegiatan }\end{array}$ & $\begin{array}{l}\text { - Membaca handout tentang } \\
\text { bagaimana keberhasilan dalam } \\
\text { kegiatan kecil-kecil akan } \\
\text { membantu meningkatkan } \\
\text { perasaan positif } \\
\text { - Membuat jadwal kegiatan yang } \\
\text { seimbang antara pekerjaan, } \\
\text { rekreasional, istirahat, personal, } \\
\text { dan sosial } \\
\text { - Memaknai setiap kegiatan yang } \\
\text { dilakukan }\end{array}$ & $\begin{array}{l}\text { - Melakukan kegiatan-kegiatan } \\
\text { yang bisa mengurangi } \\
\text { perasaan negatif dan } \\
\text { meningkatkan perasaan positif } \\
\text { - Menemukan makna dari setiap } \\
\text { kegiatan sehingga perasaan } \\
\text { menjadi lebih positif } \\
\text { - Memahami manfaat kegiatan } \\
\text { dalam upaya meningkatkan } \\
\text { perasaan positif dan } \\
\text { mengurangi perasaan negatif }\end{array}$ \\
\hline
\end{tabular}

6 Membuat jarak dengan pikiran
a. Latihan kesadaran
- Melakukan latihan-latihan kesadaran akan reaksi tubuh, pikiran, dan perasaan
b. Latihan membayangkan
- Latihan membayangkan

7 Mengatasi emosi negatif

- Berlatih mengatasi emosi negatif dengan keterampilan-keterampilan yang sudah dipelajari sebelumnya, seperti berpikir berbeda, bertindak berbeda, dan membayangkan hal-hal yang menyenangkan atau menenangkan

8 Mempertahankan

- Membuat agenda kegiatan yang kondisi positif bersifat memelihara perasaan positif dan pengelolaan pikiran yang rasional

- Meningkatkan kesadaran hubungan antara tubuh, pikiran, dan perasaan

- Meningkatkan ketenangan, kenyamanan, dan kestabilan emosi

- Meningkatkan kemampuan individu mengelola pikran dan perasaan melalui keterampilan pengubahan pikiran dan perilaku

- Memelihara kebiasaan postif yang bersifat meningkatkan atau memelihara perasaan positif dan meningkatkan cara berpikir yang rasional 
Hasil uji coba modul

Uji coba modul dilakukan selama 10 sesi, setiap sesinya berlangsung selama 2 jam. Berdasarkan pengamatan terhadap peserta, pengamatan terhadap jalannya pertemuan, dan sharing peserta, dapat dirangkum beberapa hal sebagai berikut: (1) Handout "Mengidentifikasi pikiran, perasaan, perilaku" bisa dipahami oleh subjek penelitian. (2) Lembar Kerja 1, sangat membantu klien mengidentifikasi pikiran, perasaan, perilaku dan kaitan di antara ketiganya. (3) Umpan balik yang didapat dari skor ATQ, DAS, dan BDI - II sangat membantu subjek dalam memahami handout pikiran otomatis dan pikiran tidak membantu. (4) Lembar kerja 2 dan 3 sangat membantu klien mengidentifikasi jenis-jenis pikiran negatif otomatis yang sering muncul. (5) Lembar kerja 4 dan handout: Membuat Perubahan Pikiran, Fakta dan Pendapat, Mencari Pikiran Alternatif membantu klien membedakan antara fakta dan pendapat, melihat kejadian dari berbagai sudut pandang, dan membuat pikiran subjek lebih fleksibel. (6) Lembar Kerja 5, Lembar Kerja 6, dan handout yang berjudul "Memperbaiki peraturan harus", membantu klien mencari rules yang mendasari pikiran negatif otomatis, mengujinya, dan memperbaiki rules yang semula kaku, tidak realistis menjadi lebih fleksibel dan lebih realistis.
(7) Lembar kerja 8, 9, dan handout "Perubahan Perilaku" dan "Melakukan Kegiatan" membuat klien merasa mengalami sesuatu yang baru dan lebih menemukan makna dalam hidup, sehingga mengurangi perasaan depresinya. (8) Contoh-contoh metafora dalam handout menjaga jarak dengan pikiran, tampak sangat membantu peserta mengelola pikiran dan perasaan, dan (9) Latihanlatihan kesadaran dan meditasi tidak mudah dikuasai subjek. Nampaknya untuk bisa menguasai teknik kesadaran dan meditasi dibutuhkan latihan yang bersifat rutin, konsisten, dan terus menerus.

\section{Hasil analisis statistik}

Hasil paired t-test untuk BDI-II ( $\mathrm{t}_{(25)}$ $=9,20 ; p<0,01)$, ATQ $\left(\mathrm{t}_{(26)}=3,58 ; p<0,01\right)$, dan DAS $\left(\mathrm{t}_{(26)}=4,63 ; p<0,01\right)$. Hal ini menunjukkan bahwa modul bantu diri TKP dapat mengurangi gejala depresi, pikiran negatif otomatis, dan pikiran disfungsional.

Hasil rerata skor depresi subjek penelitian pada pra uji yang berada pada kategori sedang $(23,37)$ setelah mendapatkan Terapi Kognitif Perilaku mengalami penurunan dan masuk dalam kategori normal $(6,59)$. Sementara itu rerata skor ATQ (pikiran negatif otomatis) subjek sebelum mendapatkan TKP sebesar 68,18 dan mengalami penurunan menjadi 50,07.

Tabel 2

Statistik deskriptif skor pra dan purna uji

\begin{tabular}{lrrrrrrrr}
\hline & Usia & JK & BDI_pre & BDI_post & ATQ_pre & ATQ_post & DAS_pre & DAS_post \\
\hline N Valid & 27 & 27 & 27 & 27 & 27 & 27 & 27 & 27 \\
\multicolumn{1}{c}{ Missing } & 0 & 0 & 0 & 0 & 0 & 0 & 0 & 0 \\
Mean & 20.44 & 23.37 & 6.59 & 68.19 & 50.07 & 153.11 & 111.33 \\
Median & 20.00 & 22.00 & 3.00 & 65.00 & 43.00 & 145.00 & 116.00 \\
Mode & 19 & 20 & 2 & $53^{\mathrm{a}}$ & 40 & 150 & $98^{\mathrm{a}}$ \\
Std. Deviation & 3.816 & 5.047 & 8.229 & 18.731 & 23.123 & 45.096 & 21.891 \\
\hline
\end{tabular}

a. Multiple modes exist. The smallest value is shown 
Tabel 3

Deskripsi skor pra dan purna uji berdasarkan jenis kelamin

\begin{tabular}{lcccccc}
\hline \multicolumn{1}{c}{ Jenis Kelamin } & BDI-II Pre & BDI-II Purna & ATQ-Pre & ATQ-Purna & DAS-Pre & DAS-Purna \\
\hline Perempuan & 24,26316 & 6,421053 & 72,15789 & 51,36842 & 161,6316 & 111,5263 \\
Laki-laki & 21,25 & 7 & 58,75 & 47 & 132,875 & 110,875 \\
\hline
\end{tabular}

Tabel 4

Hasil uji t skor BDI-II, ATQ, dan DAS

\begin{tabular}{|c|c|c|c|c|c|c|c|c|}
\hline & \multicolumn{5}{|c|}{ Paired Difference } & \multirow{3}{*}{$t$} & \multirow{3}{*}{ df } & \multirow{3}{*}{$\begin{array}{c}\text { Sig. } \\
\text { (2-tailed) }\end{array}$} \\
\hline & \multirow[t]{2}{*}{ Mean } & \multirow[t]{2}{*}{ SD } & \multirow[t]{2}{*}{$\begin{array}{l}\text { Std } \\
\text { Error } \\
\text { Mean }\end{array}$} & \multicolumn{2}{|c|}{$\begin{array}{c}95 \% \text { Confidence } \\
\text { Interval of the } \\
\text { Difference }\end{array}$} & & & \\
\hline & & & & Lower & Upper & & & \\
\hline Pair 1 BDI_pre-BDI_Post & 16.731 & 9.272 & 1.818 & 12.986 & 20.476 & 9.201 & 25 & .000 \\
\hline Pair 1 ATQ_pre - ATQ_post & 18.111 & 26.283 & 5.058 & 7.714 & 28.508 & 3.581 & 26 & .001 \\
\hline Pair 1 DAS_pre - DAS_post & 41.778 & 46.913 & 9.028 & 23.220 & 60.336 & 4.627 & 26 & .000 \\
\hline
\end{tabular}

Rerata skor DAS (pikiran disfungsional) subjek penelitian ini pada saat mengalami depresi sebesar 153,11 dan setelah TKP serta mengalami penurunan depresi, rerata skor DAS subjek menjadi 111,33 .

\section{Diskusi}

Modul ini memang tidak sampai pada penelusuran core belief sehingga meskipun subjek mampu melihat rules yang mendasari pikiran negatif otomatis dan disfungsional, tetapi mereka masih mengalami kesulitan mengubah pikiran yang bersifat kaku, mengharuskan, dan mengikat. Karena program bantu diri ini tidak sampai pada penelusuran dan pengubahan core bielief secara langsung, maka jika latihanlatihan kesadaran dan meditasi tidak dilakukan secara rutin dan berkelanjutan, ada kemungkinan subjek akan mengalami kembali kondisi depresi meskipun tidak seberat sebelumnya.

Kebaruan modul ini dibandingkan dengan modul yang sudah ada adalah adanya pemeriksaan diri yang nantinya umpan baliknya akan berupa program interaktif. Maksudnya ketika modul ini nantinya sudah dalam bentuk web, maka setiap orang akan mendapatkan umpan balik langsung dari setiap lembar kerja maupun beberapa alat asesmen diri yang dikerjakan. Web juga akan dirancang untuk memberikan laporan kemajuan dari setiap individu yang telah melakukan kegiatan-kegiatan yang dituliskan dalam modul. Program interaktif ini akan sangat bermanfat bagi individu untuk mengetahui kemajuan yang sudah dicapai, sekaligus sebagai sarana memotivasi individu untuk tetap melakukan latihan-latihan yang bisa membantunya meningkatkan kesehatan mental.

Hasil uji t menunjukkan bahwa modul bantu diri TKP dapat mengurangi gejala depresi, pikiran negatif otomatis, dan pikiran disfungsional. Dengan kata lain hasil penelitian ini mendukung teori kognitif Beck bahwa TKP seharusnya tidak hanya mengurangi gejala depresi tetapi juga pikiran negatif otomatis dan disfungsional.

Rerata skor ATQ subjek penelitian ini saat mengalami depresi masih lebih 
rendah jika dibandingkan dengan hasil penelitian Harrel dan Ryon (1983) serta Hollon dan Kendall (1980), yaitu 88,9 untuk penderita depresi dan 79,64 untuk mahasiswa yang mengalami depresi subklinis. Sementara skor purna uji untuk ATQ tidak jauh berbeda dari temuan Harrel dan Ryon (1983), yaitu bahwa pada sampel non depresi rerata skor ATQ sebesar 48,57 .

Jika dibandingkan dengan hasil penelitian Haeffel, dkk. (2005), rerata skor DAS pada subjek penelitian ini lebih tinggi dibandingkan dengan rerata skor penderita depresi pada penelitian Haeffel, dkk., yaitu sebesar 121,92. Sementara itu rerata skor DAS pada subjek penelitian ini setelah mengalami penurunan depresi (purna uji) menjadi lebih rendah jika dibandingkan dengan rerata skor DAS pada sampel nondepresi Haeffel, dkk. (2005), yaitu 111,33 banding 120,47.

Pada Tabel 3 dapat dilihat bahwa rerata skor depresi (BDI-II), pikiran negatif otomatis (ATQ), dan pikiran disfungsional (DAS) pra uji pada subjek perempuan lebih tinggi dibandingkan laki-laki. Hal ini sejalan dengan temuan-temuan sebelumnya bahwa prevalensi perempuan untuk mengalami depresi lebih tinggi dibandingkan laki-laki. Demikian halnya dengan kecenderungan berpikir negatif dan irasional.

Kajian teoretis dan hasil-hasil penelitian menunjukkan bahwa perbedaan prevalensi depresi dan somatisasi antara laki-laki dan perempuan ini berkaitan dengan faktor biologis dan konstruksi sosial-budaya. Secara biologis tingginya kecenderungan depresi pada perempuan merupakan akibat langsung dari hormon sel telur (khususnya estrogen dan progesteron) terhadap perubahan suasana hati (Nolen-Hoeksema, 2001). Perempuan akan lebih depresi pada saat periode perubahan hormonal seperti pubertas, periode premenstrual, menopause, ataupun pasca melahirkan.

Studi lebih baru menunjukkan bahwa perempuan lebih cenderung mengalami disregulasi hipotalamus-pituitari-adrenal (aksis HPA) yang berperan dalam mengatur respons stres (Weiss, Longhurst, \& Mazure, 1999 dan Young \& Korszun dalam Nolen-Hoeksema, 2001). Hal ini disebabkan oleh sifat hormon sel telur yang memodulasi regulasi aksis HPA. Oleh karena itu perempuan cenderung mengalami depresi pada saat terjadinya perubahan hormonal yang cepat, yaitu pada saat pubertas, pramenstrual, menopause, dan pasca melahirkan.

Dari segi faktor sosial budaya, perbedaan prevalensi depresi pada perempuan dan laki-laki berkaitan dengan konstruksi sosial budaya yang melekat pada kedua jenis kelamin tersebut (Freund \& McGuire, 1991). Dalam proses sosialisasi, perempuan diharapkan mengembangkan femininitas, yaitu orientasi komunal seperti keterampilan membina hubungan dengan orang lain, emosional, dan kehangatan; sedangkan laki-laki diharapkan mengembangkan maskulinitas, yaitu orientasi otonomi seperti kemandirian, kemampuan berkompetisi, dan keyakinan diri (Lewis, 1985; Sanfilipo, 1994).

Konsep diri perempuan lebih dilekatkan kepada relasi interpersonal, sementara itu konsep diri laki- laki lebih dilekatkan pada hak-hak pribadi, dan otonomi (Nolen-Hoeksema, 2001; Rosenfield, Vertefuille, \& Mcalpine, 2000). Oleh karena manusia pada dasarnya adalah mahluk sosial, maka kecenderungan perempuan yang lebih berorientasi komunal ini menyebabkan mereka lebih rentan terhadap stresor interpersonal seperti konflik atau putusnya relasi dengan orang lain yang dapat berkembang menjadi keadaan 
depresif (Nolen-Hoeksema, 2001; Wiseman, Hadas, Guttfreund, \& Daniel, 1995). Hasil penelitian Leadbeater, Blatt, dan Quinlan (1995) menunjukkan bahwa perempuan cenderung menderita depresi interpersonal dan lebih reaktif terhadap stres yang dialami oleh orang lain.

Konstruksi sosial budaya pada perempuan juga menghendaki perempuan bersikap halus dan sopan, sehingga mereka tidak diharapkan untuk mengekspresikan kemarahan, terutama dalam berelasi dengan orang lain. Oleh karena itu pada umumnya perempuan cenderung mengarahkan kemarahan kepada diri sendiri (anger in) yang bisa menyebabkan internalizing disturbance seperti kecemasan, bunuh diri, dan gangguan makan serta menguatkan ekspresi depresi yang berupa gejala somatik, perasaan sedih, dan kesepian (Leadbeater, Blatt, \& Quinlan, 1995; Silverstein, Caceres, Perdue dkk., 1995; Silverstein \& Blumenthal, 1997); Silverstein \& Lynch, 1998); Silverstein, 1999; 2002).

Sementara itu laki-laki diharapkan lebih ekspresif dan maskulin, sehingga kemarahan merupakan emosi utama lakilaki yang mencerminkan kejantanan dan maskulinitas. Oleh karena itu laki-laki pada umumnya mengekspresikan kemarahan mereka kepada objek di luar dirinya (anger out). Menurut Leadbeater, Blatt, dan Quinlan (1995), kemarahan yang diarahkan keluar menyebabkan laki-laki cenderung mengalami externalizing disturbance seperti gangguan oposisional, kenakalan, dan masalah sekolah serta menguatkan ekspresi depresi yang berupa antagonisme, agresi, dan ketidakmampuan bekerja.

Meskipun demikian jika dilihat penurunan rerata skor pada purna uji, subjek perempuan lebih banyak menunjukkan penurunan dibandingkan laki-laki, baik pada skor BDI-II, ATQ, dan DAS. Hal ini menunjukkan bahwa perempuan lebih mendapatkan manfaat terapi dibandingkan laki-laki.

Konstruksi sosial budaya terhadap laki-laki dan perempuan, mungkin mempunyai pengaruh terhadap tingginya responsivitas perempuan terhadap terapi dibandingkan laki-laki. Seperti sudah dijelaskan sebelumnya bahwa perempuan lebih dipengaruhi oleh relasi sosial (Dion \& Dion, 1993), maka kemungkinan efek terapi kelompok pada perempuan yang lebih besar dibandingkan laki-laki disebabkan oleh perasaan diterima dan didukung di dalam kelompok. Kesempatan untuk mengekspresikan pikiran, perasaan, dan pengalaman; saling menanggapi dan meneguhkan dalam terapi kelompok lebih menguntungkan perempuan dibandingkan laki-laki.

Kemungkinan lain adalah proses interaksi dalam terapi kelompok lebih berpengaruh terhadap penurunan pikiran disfungsional pada perempuan. Jika dicermati, pikiran-pikiran disfungsional pada subjek penelitian ini berkisar tentang rendahnya harga diri dan penerimaan diri. Seperti telah diuraikan sebelumnya bahwa harga diri perempuan lebih dilekatkan pada penerimaan sosial dibandingkan laki-laki, maka penerimaan kelompok menyebabkan para anggotanya, terutama perempuan mengalami peningkatan penerimaan diri dan penurunan pikiran-pikiran disfungsional yang berkaitan dengan kebutuhan untuk diterima dan kecemasan akan penolakan lingkungan. Situasi saling mendukung dalam kelompok dan latihanlatihan untuk menerima diri dan orang lain tanpa syarat, mungkin banyak membantu perempuan dalam mengelola pikiran dan perasaannya saat berelasi dengan orang lain, khususnya dalam hal mengubah peraturan "harus" dan "seharusnya". Perempuan menjadi lebih mampu 
mengubah peraturan "harus" dan "seharusnya" yang merupakan hasil internalisasi dari tuntutan sosial terhadap perempuan.

Efek terapi kelompok yang lebih besar pada perempuan dibandingkan laki-laki dalam penelitian ini mungkin juga disebabkan oleh sikap submisif perempuan yang lebih tinggi dibandingkan lakilaki. Tuntutan sosial yang menghendaki perempuan lebih rendah hati dan patuh (submisif) (Madson \& Trafimow, 2001), kemungkinan menyebabkan perempuan lebih mudah menerima masukan dari orang lain sehingga lebih responsif terhadap terapi. Sementara itu konstruksi sosial maskulinitas terhadap laki-laki yang menghendaki kemandirian, ketangguhan, kepercayaan pada diri sendiri, dan dominan (Madson \& Trafimow, 2001), mungkin menyebabkan laki-laki kurang mudah menerima masukan dari orang lain sehingga kurang responsif terhadap terapi.

\section{Kesimpulan}

Hasil uji coba modul bantu diri TKP menunjukkan bahwa modul ini dapat menurunkan gejala depresi, pikiran negatif otomatis, dan pikiran disfungsional. Meskipun demikian, karena tidak adanya kelompok kontrol, maka perlu disadari adanya kemungkinan error atau bias yang disebabkan oleh ancaman terhadap validitas penelitian misalnya efek kematangan, sejarah, pengalaman, dan regresi statistik. Oleh karena itu untuk penelitian tahap selanjutnya, perlu ditingkatkan validitas penelitian melalui desain pra dan pasca uji coba dengan kelompok kontrol dan eksperimen.

\section{Kepustakaan}

American Psychiatric Association. (2000). Practice Guideline for the treatment of patients with major depressive disorder (revision). Am J Psychiat, 157, 1-45.

American Psychiatric Association (2010). Practice Guideline for the treatment of patients with major depressive disorder. http://dx.doi.org/10.1176/appi.books.97 80890423387.654001 atau Psychiatriconline.org/content.aspx?bookid=28\&sec tionid $=1667485$

Andersson, G., \& Cuijper, P. (2009). Internet-based and other computerized psychological treatments for adult depression: A meta-analysis. Cognitive Behaviour Therapy, 38(4), 196-205.

Andrews, G., \& Titov, N. (2007). Depression is very disabling. Lancet, $370,808-$ 809.

Beck, A. T. (1985). Depression: Causes and treatment. Philadelphia: York International of Pensylvania press.

Beck, A. T., Steer, R. A., \& Brown, G. K. (1996). BDI-II, Beck Depression Inventory: Manual ( $2^{\text {th }}$ ed.). Boston: Harcour,Brace, and Company.

Berger, Th., Ha"mmerli1, K., \& Gubser, N. (2011). Internet-based treatment of depression: A randomized controlled trial comparing guided with unguided selfhelp. Cognitive Behaviour Therapy, 40(4), 251-266.

Buczynski, R. (T.t.). A mind body/medicine update: what every practitioner needs to know. The National Institute for the Clinical Application of Behavioral Medicine.

Burns, D. D. (1988). Terapi Kognitif, pendekatan baru bagi penanganan depresi (Santoso, terj). Jakarta: Penerbit Erlangga 
Chiu E. (2004). Epidemiology of depression in the Asia Pacific region. Australasian Psychiatry, 12, 4-10.

Ciarrochi, J., \& Bilich. L. (2006). Acceptance and commitment therapy. School of Psychology, University of Wollongong.

Clarke, G., Kelleher, Ch., Hornbrook, M., DeBar, L., Dickerson, J., \& Gullion, Ch. (2009). Randomized effectiveness trial of an internet, pure self-help, Cognitive Behavioral Intervention for depressive yymptoms in young adults. Cognitive Behaviour Therapy, 38(4), 222-234.

Davidson, R. J., Kabat-Zinn, J., Schumacher, J., Rosenkranz, M., Muller, D., Santorelli, S. F., Urbanowski, F., Harrington, A., Bonus, K., \& Sheridan, J. F. (2003). Alterations inbrain and immune function produced by mindfulness meditation. Psychosomatic Medicine, 65(4), 564-570.

Dion, K., \& Dion, K. L. (1993). Individualistic and collectivistic perspectives on gender and the cultural context of love and intimacy. Journal of Social Issues, 49(3), 53-69.

Dobson, K. S., \& Dozois, D. J. (2010). Historical and philosophical bases of cognitive-behavioral therapies. Dalam Dobson, K.S. (Ed). Handbook of Cognitive-Behavioral Therapies (h. $3-38$ ). New York: The Guilford Press.

Dowd, E. T. (2004). Depression: theory, assessment, and new direction in practice. International Journal of Clinical and Health Psychology, 4 (2), 413-423.

Dusek, J. A., Otu, H. H., Wohlhueter, A. L., Bhasin, M., Zerbini, L. F., Joseph, M. G., Benson H., \& Libermann T. A. (2008). Genomic counter-stress changes induced by the relaxation response. PLoS ONE [Electronic Resource], 3(7), e2576.http://.dx.doi.org/10.1371/journal. pone.0002576.
Ebrahimi, A., Afshar, H., Doost, H. T. N., Mousavi, S. G., \& Moolavi. H. (2012). Attitude scale and general health questionnaire subscales predict depression? J Res Med Sci., 17(1), 40-44.

Epp, A. M., \& Dobson, K. S. (2010). The evidence base of Cognitive-Behavioral Therapy. Dalam Dobson, K.S. (Ed). Handbook of Cognitive-Behavioral Therapies (h. 39 - 73). New York: The Guilford Press.

Freund, P. E. S., \& McGuire, M. B. (1991). Health, illness, and the social body: ACritical Sociology. New Jersey: Prentice-Hall.

Fruzzetti, A. E., \& Erikson, K. R. (2010). Mindfulness and acceptance interventions in cognitive-behavioral therapy. Dalam Dobson, K.S. (Ed). Handbook of Cognitive-Behavioral Therapies (h. 347 372). New York: The Guilford Press.

Ginting, H., Näringa, N., Van der Velda, W. M., Srisayektic, W., \& Beckera, E. S. (2013). Validating the Beck Depression Inventory-II in Indonesia's general population and coronary heart disease patients. International Journal of Clinical and Health psychology, 13, 235-342.

Goldman, L. S, Nielson, N. H., \& Champion, N. C. (1999). Awareness, diagnosis, and treatment of depression, Clinical Review, 14, 569-580.

Haeffel, G. J., Abramson, L. Y., Voelz, Z. R., Metalsky G. I., Halberstadt, L., Dykman, B. M., Donovan, P., Hogan, M. E., Hankin, B. L., \& Alloy, L. B. (2005). Negative cognitive styles, dysfunctional attitudes, and the remitted depression paradigm: a search for the elusive cognitive vulnerability to depression factor among remitted depressives. Emotion, 5(3), 343-348.

Harrell, T. H., \& Ryon, N. B. (1983) Cognitive-Behavioral Assessment of Depression:Clinical Validation of the Auto- 
matic Thoughts Questionnaire. Journal of Consulting and Clinical Psychology, 51(5), 721-725.

Hollon, S. D., \& Kendall, P. C. (1980). Cognitive self-statements in depression: Development of an Automatic Thoughts Questionnaire. Cognitive Therapy and Research, 4, 383 - 395.

Hölzel B. K., Carmody J., Vangel M., Congleton C., Yerramsetti S. M., Gard T., \& Lazar, S. W. (2011). Mindfulness practice leads to increases in regional brain gray matter density. Psychiatry Res. 191(1), 36-43.

Immerman, R. S., \& Mackey, W. C. (2003). The depression gender gap: A view through a biocultural filter. Genetic, Social, and General Psychology Monographs, 129(1), 5 -39.

Infante, J. R., Peran, F., Martinez, M., Roldan, A., Poyatos, R., Ruiz, C., Samaniiego, F., \& Garrido, F. (1998). $\mathrm{ACTH}$ and $\beta$-endorphin in transcendental meditation. Physiology $\mathcal{E}$ Behavior, 64(3), 311-315.

Idusohan-Moizer, Sawicka, A., Dendles, J., \& Albany, M. (2013). Mindfulnessbased cognitive therapy for adults with intelectual disabilities: an evaluation of the effectiveness of mindfulness in reducing symptoms of depression and anxiety. Journal of Intellectual Dissability Research, 1-1 2. http://dxdoi.org/10.1111 /jir.12082

International Test Commission (2010). International test commission guidelines for translating and adapting tests. Diunduh dari: http://www.intestcom.org

Jeannette Rosselló, J., Bernal, G., \& Piedras, R. (2007). Treatment manual for cognitive behavioral therapy for depression: adaptation for puerto rican adolescents, based on the Group Therapy Manual for Cognitive-behavioral Treatment of Depression Ricardo F.
Muñoz, Ph.D. Sergio Aguilar-Gaxiola, M.D., Ph.D. John Guzmán, Ph.D. San Francisco General Hospital, Depression Clinic

Jumlah Penduduk yang Depresi Meningkat. (2012). Diunduh dari: http://health. kompas.com/read/2012/10/06/02221686/ Jumlah.Penduduk.yang.Depresi.Menin gkat.

Kane, P., \& Garber, J. (2004). The relations among depression, in fathers, children's psychopatology, and father-child conflict: A meta-analysis. Clinical Psychological Review, 24, 339-360.

Kaplan, H. I., \& Sadock, B. J. (1991) Synopsis of psychiatry: Behavioral sciences and clinical psychiatry (ed. Ke-6.). Baltimore, MD: William \& Wilkins

Kazdin, A. E. (1990). Evaluation of the automatic thoughts questionnaire: negative cognitive processes and depression among children. Psychological Assessment: A Journal of Consulting and Clinical Psychology, 2(1), 73-79

Kerlinger, F. N. (1990). Asas-asas penelitian behavioral (ed ke -3). (Simatupang, L.R. terj). Yogyakarta: Gadjah Mada University Press. (karya asli terbit tahun 1986).

Leadbeater, B. J., Blatt, S. J., \& Quinlan, D. M. (1995). Gender-linked vulnerebalities to depressive symptoms, stress, and problem behaviors in adolescents. Journal of Research on Adolescence, 5(1), 1-29.

Leedy, P. D., \& Ormrod, J. E. (2005). Pratical research. Planning and design ( $8^{\text {the }}$ ed.). Upper Saddle River, NJ: Pearson.

Madson, L., \& Trafimow, D. (2001). Gender comparison in the private, collective, and Allocentric selves. The Journal of Social Psychology, 141(4), 551559.

MacLean, C. R., Walton, K. G., Wenneberg, S. R., Levitsky, D. K., Mandarino, J. P., Waziri, R., Hillis, S. L., \& Schneider R. 
H. (1997). Effects of the transcendental meditation program on adaptive mechanisms: changes in hormone levels and responses to stress after 4 months of practice. Psychoneuroendocrinology, 22(4), 277-295.

McGinn, L. K. (2000). Cognitive behavioral therapy of depression: theory, treatment, and empirical status. American Journal of Psychotherapy. 54, issue 2.

Muñoz, R. F., Ippen C. G., Rao, S., HuynhNhu Le, \& Dwyer, E. V. (2000). Manual for group cognitive-behavioral therapy of major depression: a reality management Approach(Instructor's Manual). San Francisco: Cognitive-Behavioral Depression Clinic Division of Psychosocial Medicine San Francisco General Hospital University of California.

Mukhtar, F., Oei, T. P. S., \& Yaacob, M. J. M. (2011). Effectiveness of group cognitive behaviour therapy augmentation in reducing negative cognitions in the treatment of depression in malaysia. ASEAN Journal of Psychiatry, 12(1), 50-65.

National Institute of Mental Health. (2002). Depression. Diunduh dari: http://www. nimh.nih.gov.

Neenan, M., \& Dryden, W. (2004). Cognitive Therapy:100 key points $\mathcal{E}$ technique. New York: BrunnerRoutledge

Neuman, W. L. (2000). Social Research Methods: Qualitative and Quantitative Approaches. Boston: Allyn and Bacon.

Newberg, A., \& Iversen, J. (2003).The neural basis of the complex mentaltask of meditation: neurotransmitter and neurochemical considerations. Medical Hypotheses, 61(2), 282-291.

National Institute of Mental Health. (2006). Depression. Diunduh dari: www.nimh. nih.gov/publicat/depressionmenu.cfm. tanggal 10 Maret 2007.
Nolen-Hoeksema, S. (1994). An interactive model for the emergence of gender differences in depression in adolescence. Journal of Research on Adolescence, 4(4), 519-534.

Petrocelli, J. V. (2002). Effectiveness of group cognitive-behavioral therapy for general symptomatology: a metaanalysis. Journal For Specialists In Group Work, 27(1), 92-115

Retnowati, S. (2004). Depresi remaja: Metode integrasi penyebab depresi dan pengatasan depresi pada remaja. (Disertasi tidak dipublikasikan). Yogyakarta: Universitas Gadjah Mada.

Retnowati, S. (2011). Psikolog puskesmas: kebutuhan dan tantangan bagi profesi psikologi klinis Indonesia. (Pidato pengukuhan guru besar, tidak dipublikasikan), Universitas Gadjah Mada, Yogyakarta, Indonesia.

Rosenfield, S., Vertefuillem J., \& McAlpine, D. D. (2000). Gender stratification and mental health: An exploration of dimensions of the self. Social Psychology Quarterly, 63(3), 208-223.

Shaughnessy, J. J., Zechmeister, E. B., \& Zechmeister, J. S. (2007). Metode Penelitian Psikologi (terjemahan). Yogyakarta: Pustaka Pelajar.

Silverstein, B., Caceres, J., Perdue, L., \& Cimarolli, V. (1995). Gender differences in depressive symptomatology: The role played by "anxious somatic depression" associated with genderrelated achievement concerns. Academic Research Library, 33, 621- 636.

Silverstein, B., \& Blumenthal, E. (1997). Depression mixed with anxiety, somatization, and disordered eating: Relationship with gender-role-related limitation experienced by females. Sex Roles, 36, 709 - 717.

Silverstein, B., \& Lynch, A. D. (1998). Gender differences in depression: The 
role played by paternal attitudes of male superiority and maternal modeling of gender-related limitations. Sex Roles, 38, 539-555.

Silverstein, B. (1999). Gender difference in the prevalence of clinical depression: The role played by depression associated with somatic symptoms. The American Journal of Psychiatry, 156, 480482.

Silverstein, B. (2002). Gender differences in the prevalence of somatic versus pure depression: A replication. The American Journal of Psychiatry, 159, 1051-1052.

Tinas Psikologi. (2012). Мепијu Manusia Indonesia Sehat Mental. diunduh dari: http://www.unair.ac.id/berita.unair.php ?id=1435

Tooley, G. A., Armstrong, S. M., Norman, T. R., \& Sali A. (2000). Acute increases in night-time plasma melatonin levels following a period of meditation. Biological Psychology, 53(1), 69-78.

Vivyan, C. (2009 - 2013). An Introductory self help course in Cognitive Behavior Therapy. Diunduh dari: www.get.gg/ selfhelpassist.htm.
Wang, P. S., Simon, G., \& Kessler, R. C. (2003). The economic burden of depression and the cost-effectiveness of treatment. Int J Methods Psychiatr Res, 12(1), 22-33.

Waspadai Peningkatan Penderita Depresi. (2012). Suara Pembaharuan, hal. 6.

Weissman, A. N., \& Beck, A. T. (1978). Development and validation of the Dysfunctional Attitudes Scale: a preliminary investigation. In: Proceedings of the meeting of the American Educational Research Association. Toronto, ON

Wiseman, H., Guttfreund, D. G., \& Lurie, I. (1995). Gender differences in loneliness and depression of university students seeking counseling. British Journal of Guidance and Counseling, 23(2), 231-143.

World Health Organization. (2001). The World health report 2001: Mental health: New understanding, new hope. France

World Health Organization. (2005). Depression. Diunduh dari: http://www. who.int/mental_health/depression/defi nition. 